\title{
研究
}

$$
\begin{aligned}
& \text { ピストンポンプにおける弁板・シリンダブロック网の泪消特性“ } \\
& \text { 山口惊"*成根弘我"** } \\
& \text { 清水誠二**石田周—“*** }
\end{aligned}
$$

\section{Bearing/Seal Characteristics of the Film between a Valve Plate and a Cylinder Block of Axial Piston Pumps (3rd Report: Effects of Fluid Types and Theoretical Discussions)}

\author{
Atsushi YAMAGUCHI, Hiroyoshi SEKINE, Seiji SHIMIZU and Shuichi ISHIDA
}

\section{Summary}

An experimental study was carried out to clarify the effects of fluid types on the bearing/seal characteristics of the fluid film between a valve plate and a cylinder block of axial piston machines. The fluids tested were a kerosene, a solution type and a emulsion type high water base fluids.

Including the results with petroleum based hydraulic fluids already reported, it can be seen that: (1) For the low viscosity fluids, the reduction in the load carrying capacity is compensated for the increase in both the inclination of the wedge film and amplitude of the squeeze film. Then, on the average, the fluid film can be as thick as the petroleum based fluids.

(2) The lost power due to the frictional torque is smaller for the low viscosity fluids, but that due to the leakage flow for the petroleum based fluids. Since the latter is the dominating cause for this test, the total lost power of the low viscosity fluids is smaller only under the relatively low pressure conditions.

Moreover, it was shown that the theoretical film thickness, obtained by the calculation including the spring effect of the shaft, agreed approximately with the experimental film thickness.

\section{1. はじめに}

ピストンポンプ，モータにおいて弁板とシリンタプ

* 昭和62年 4 月 15 日 原稿受付

**横浜国立大学（广240 横浜市保土ケ谷区常盤 台 156)

***東芝

****本田技研工業
ロック間の渭動部は，その性能に大きな影要を及ぼす。 このため，乙の濖㲜部を模型化した実糇装置により． 石油系作勤油 液2)を用いた場合の状況をすでに報告した。本㫰告で は，希积倍率を変えたソリューション形作動液と，エ マルション形作動液ならびに低粘度鉱油である灯油を 用いた実験を加えて，作動流体の物性がこの揌動部の 特性に及ぼす影整を理するとともに，理詥的に求め たすきま厚さを実験値と比䎦して，設計上の指針を与 
えるととを目的とする。

\section{2. 纪 昂}

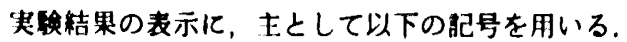

$h$ :すきま厈さ

h。：等価すきま厚さ

$\left.h_{i} （ i=1 \sim 4\right) ： \neq ゙$ さの測定値

$L:$ 损失娌力

$n$ :回坛数

$p$ : 圧力（ケ゚ージ至）

$p_{1}:$ 入口压力

$Q$ : 濖助部漏九流每

$\tau:$ 粙トルク

$t:$ 并板温度

$t_{s}:$ 作野流体の人口温度

\section{3. 実挽装置およひ方法}

実段装䈯をFig.1亿，并板形状および寸法をFig.2， Table 1 に示す．V.P.は并板の，G.S.は流体膜

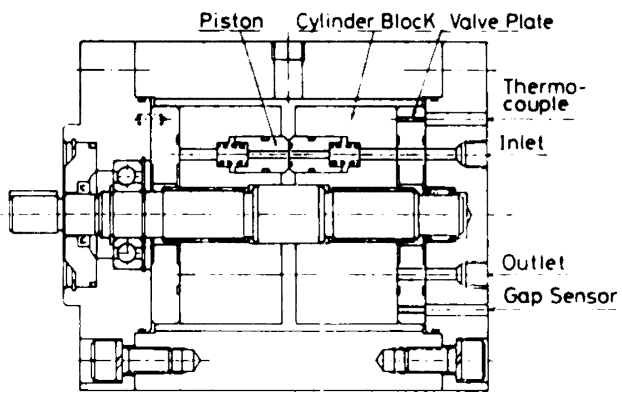

Fig. 1 Test apparatus

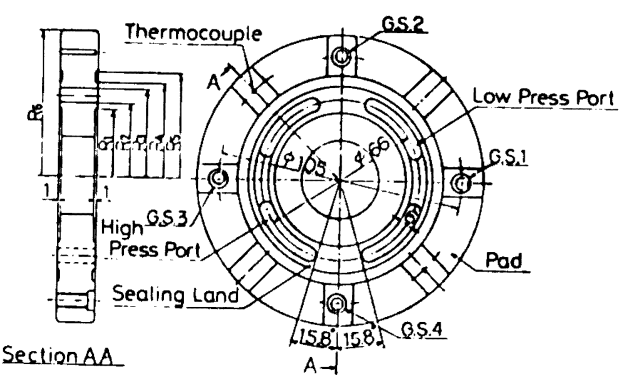

Fig. 2 Tested valve plate (G.S.: gap sensor)
Table 1 Dimensions of tested valve plates (V.P.: valve plate)

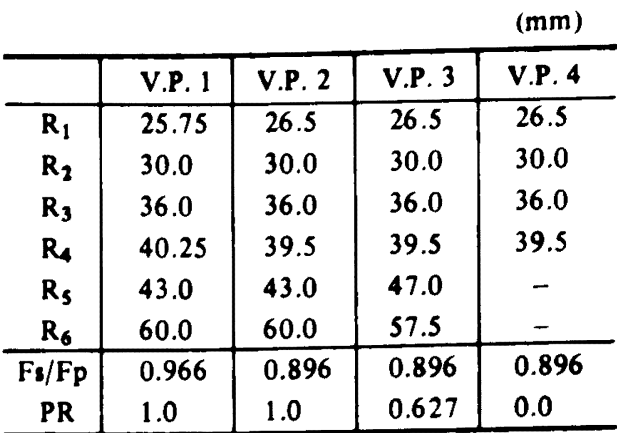

Fs: Separating force, Fp: Pushing force,

PR: Pad area ratio

Table 2 Properties of tested fluids at $t_{s}$

\begin{tabular}{l|c|c}
\hline \multicolumn{1}{c|}{ Fluid } & $\begin{array}{c}\text { Kinematic viscosity } \\
\left(\mathrm{mm}^{2} / \mathrm{s}\right)\end{array}$ & $\begin{array}{c}\text { Density } \\
\left(\mathrm{g} / \mathrm{cm}^{3}\right)\end{array}$ \\
\hline $\begin{array}{l}\text { Petroleum } \\
\text { based fluid }\end{array}$ & $30.0\left(40^{\circ} \mathrm{C}\right)$ & 0.849 \\
$14.8\left(60^{\circ} \mathrm{C}\right)$ & 0.838 \\
\hline Kerosene & 1.5 & 0.792 \\
\hline $90 \%$ Solution & 2.3 & 1.004 \\
$95 \%$ Solution & 1.0 & 0.999 \\
\hline $90 \%$ Emulsion & 0.73 & 0.996 \\
$95 \%$ Emulsion & 0.68 & 0.997 \\
\hline
\end{tabular}

90\%: deionized water $/$ concentrate $=9 / 1$,

95\%: $=19 / 1$

Compositions of the concentrates: solution type - polyalkylene glycol $30 \mathrm{w} \%$, fattyacid amine salt $25 \mathrm{w} \%$, water $39 \mathrm{w} \%$; emulsion type - mineral oil $29 w \%$, water $66 w \%$.

厚さ検出器（ギ+ップセンサ）の略である．てれらを

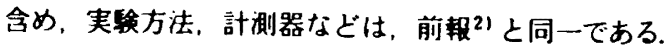
供試作動流体の動粘度と密度をTable 2 亿示す。表に は，比較の便宜上，既軙の作動流体についても示して あろ.なお，90\%は原液を1：9，95\%は1：19の割 合でイオン交換水により希釈したてとを示す.

\section{4. 実倹結果およひ考察}

すきま厚さ $h$ の变動波形をFig. 3 ～6 亿示す.V.P. 3 について $90 \%$ エルションを例にとると, $p_{s}=11.8$ $\mathrm{MPa}, n=1500 \mathrm{rpm}$ ではG.S, $1\left(h_{1}\right)$ が全振幅とし

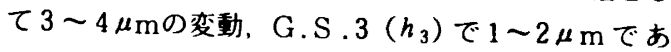
ろ. 圧力の增大につれ変動も大きくなるが, 回転数に ついては 500rpmで同程度, 3000 rpmでは小さくなる. 


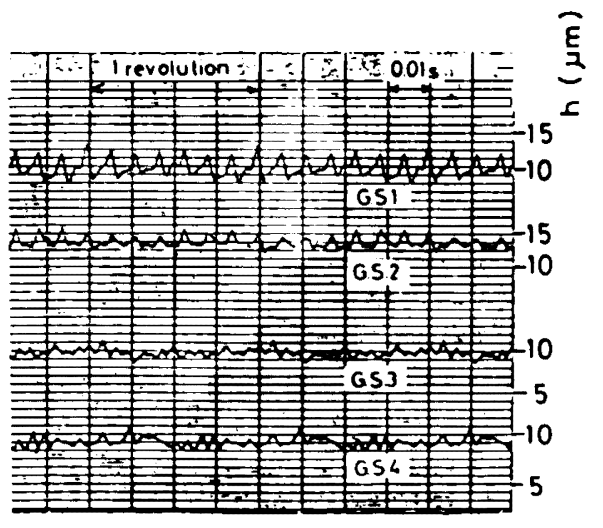

Fig. 3 Traces of fluid film thickness $h$ (V.P.3, 90\% Emulsion, 1500 rpm, (11.8 MPa)

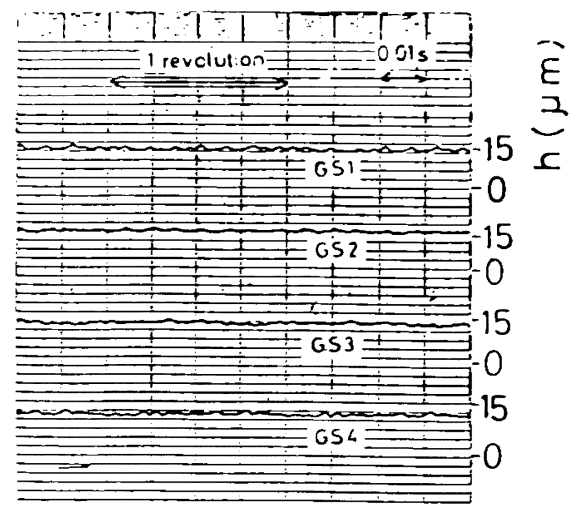

Fig. 4 Traces of fluid film thickness $h$ (V.P.3, Kerosene, $1500 \mathrm{rpm}$, 14.7 MPa)

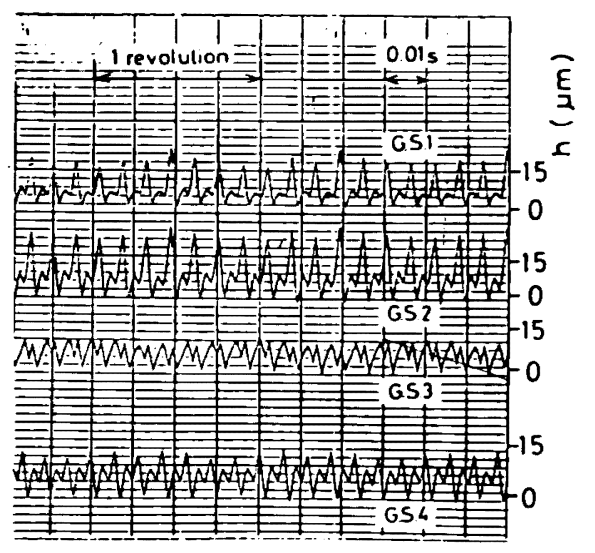

Fig. 5 Traces of fluid film thickness $h$ (V.P.4, 90\% Emulsion, 1500 rpm, $11.8 \mathrm{MPa}$ )

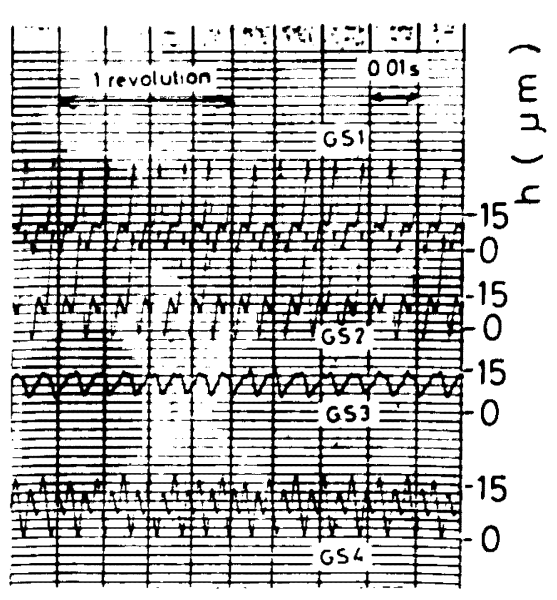

Fig. 6 Traces of fluid film thickness $h$ (V.P.4, Kerosene, $1500 \mathrm{rpm}$, $14.7 \mathrm{MPa}$ )

90\%ソリューションでの変勘は, 909×マルションに はぼ同じであるが，奵油での変劷は相当小さい，V.P. 4 の婸合, $90 \%$ エマルション $\left(p_{s}=11.8 \mathrm{MPa}, n=\right.$ $1500 \mathrm{rpm}$ )で 1 回坛当りピストン本数の 2 倍の 14 山の

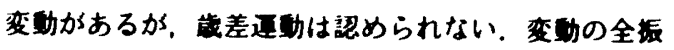

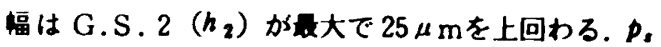
の增大につれ振愊6增すか，回転数（ $n=500 \sim 3000$ rpm）による差は琶められない.ただし，3000 rpmで は波形が整っている.90\%エマルションに比へて95\% エマルションの变功振幅はほぼ同じ，奵油は多少大き く、90\%ソリューションも大きい，作野流体、通軾条 件を同一として，V.P. 3 と 4 を比校すると，変轩はい ずれる外周バッドのない後者かかなり大きい。なお， Fig.6のG.S.2の最小值か負値となっているが、てれ

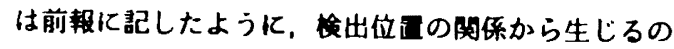
であって，金属接触や望差を意味しない。

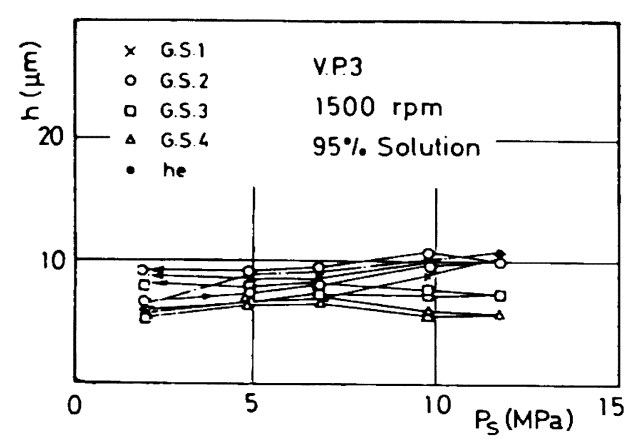

Fig. 7 Film thickness versus inlet pressure Ps for V.P.3 


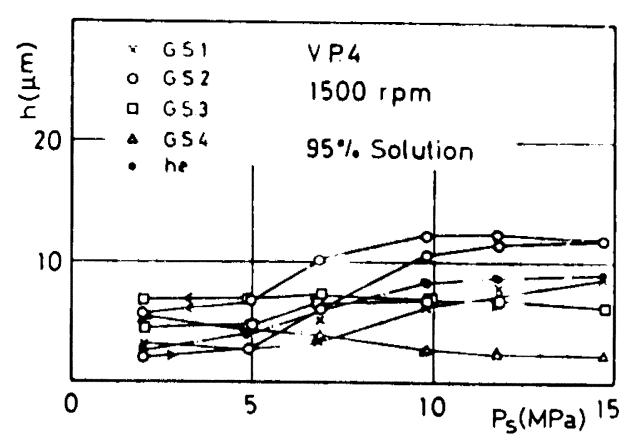

Fig. 8 Film thickness versus inlet pressure Ps for V.P.4

hの平均値と入口圧力の成係を Fig. 7 と8に小す. 実段は回枟数一定の下に，p，を增大させ，ついで成少 させる順序で行っているか，hの值はp，の增減で差を 牛じる。このため，罒中に矢印で順序を示した。全体 として，增压過程に比へ減压逦程でのhが大きい。乙 の展歴現象は，石油系作娌油ではあまり目立たなかっ たが，奵油を含め高含水作動旅ではいずれる瑟められ た。 また，p，の增大沉つんの增大する煩向は，作動 油の場合を除き，一般に珰められた。なお，すで指 摘したように，G.S.2での平均すきまが取る大きくな ろ. 图中のh。は，すきまが一模で半周分から䦗れを生 じるとして算出した等価すきまである，すなわち

$$
\begin{aligned}
& \quad h_{0}=\left[\begin{array}{ll}
\frac{12 \mu Q}{\pi p_{s}} & \frac{\ell_{n}\left(R_{2} / R_{1}\right) \ell_{n}\left(R_{\sqrt{ }} R_{3}\right)}{\ell_{n}\left(R_{2} / R_{1}\right)+\ell_{n}\left(R_{\sqrt{ }} R_{3}\right)}
\end{array}\right]^{1 / 3} \\
& \text { ここに, } \mu: \text { 粘度. }
\end{aligned}
$$

本実験装珇では，Oリンクによってピストンまわり の漏れを防止し，并板・シリンタプロック間の漏れ流 量を測定しているが（測定流国の1/2を単 1 の渭動部の Qとしている)，Qとp，の関係をFig. 9 と10亿示す.

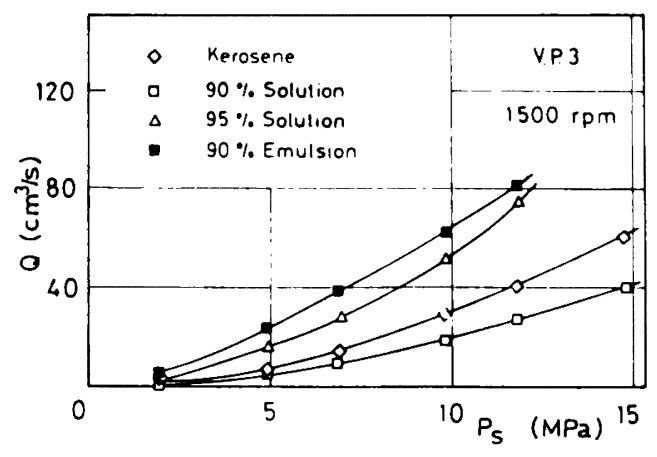

Fig. 9 Leakage flow rate $Q$ versus $P$ s for V.P.3

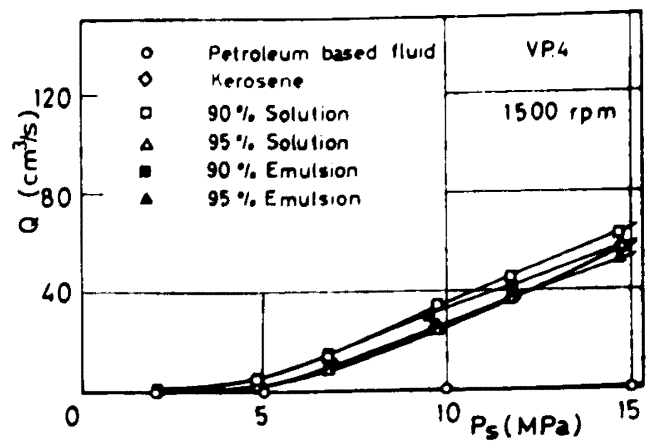

Fig. 10 Leakage flow rate $Q$ versus $P s$ for V.P.4

外周パッドのおるV.P. 3 では，和度の场合はどQ は小さくなり，特に $1500 \mathrm{rpm} て ゙ は は$ 逆比の成保 となっている。っまり，すきま里さははは同一となっ ている(Fig.11). V.P.4については，6原の作流

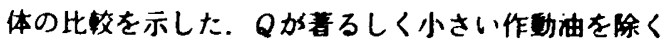
と，粘度の影はあまり認められない。しかし，比校 的高任領城では，轳度取大の909\%リューションで 6樶大，最小粘度の95\%エマルションで尉小となって いる. Fig.12䎲等価すきま厚さを示す. 90\%・リュー ションのh。の大きいてとが瑟められ，また作㶭油のh。 は小さく，作動液之は煩向の異なることが分る。

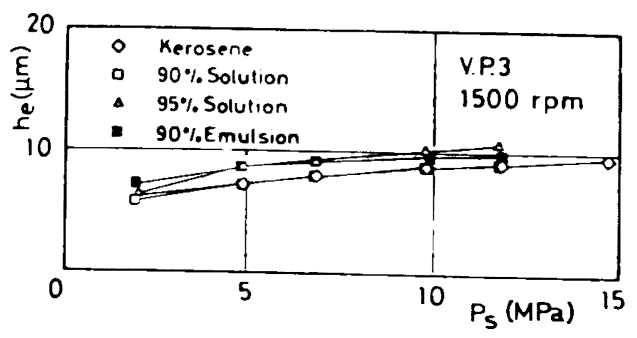

Fig. 11 Equivalent film thickness he versus Ps for V.P.3

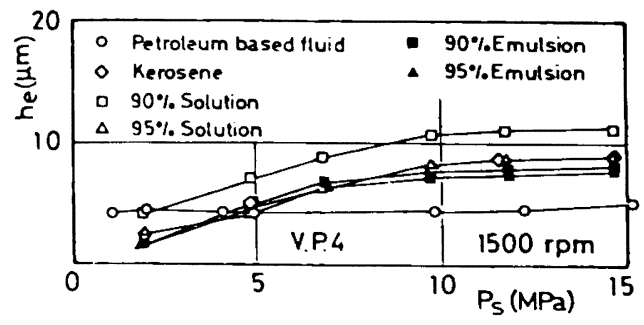

Fig. 12 Equivalent film thickness he versus Ps for V.P.4 


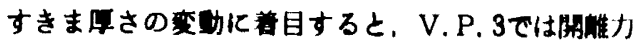
の不足分をバッド部のくさび膜奻果に，V.P.4では絞 り膜奻果に像存していることが分る。

油トルク $T$ ，弁板温度 $t$ とD。の成係を，作较流体を バラメータとしてFig. 13，14亿示す． $T$ は测定䛧を1/2

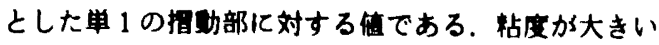
はどTの值は大きく，特に作助油(V.P.4)では，作

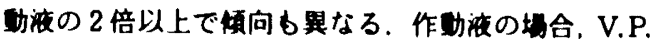

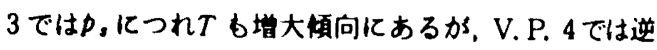

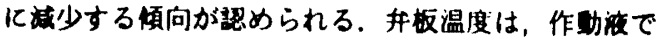
は $t$ ，との差異はわずかであろが，作咖油では $t$,より相 当上㫒している．乙れは，作轩济が低粘度であること （結果としてQが大きくTは小さい）および繁物性值 の大きいととにより説明できる. 奵油の $t$ が作朝波よ り大きいのは，缹物性值としては作助油に近いことに よろ.

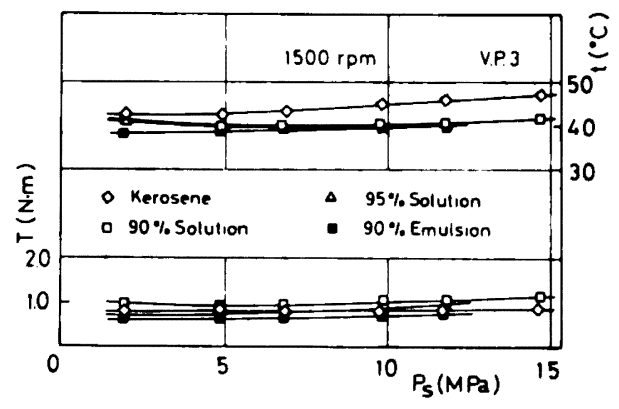

Fig. 13 Valve plate temperature $t$ and shaft torque T versus Ps for V.P.3

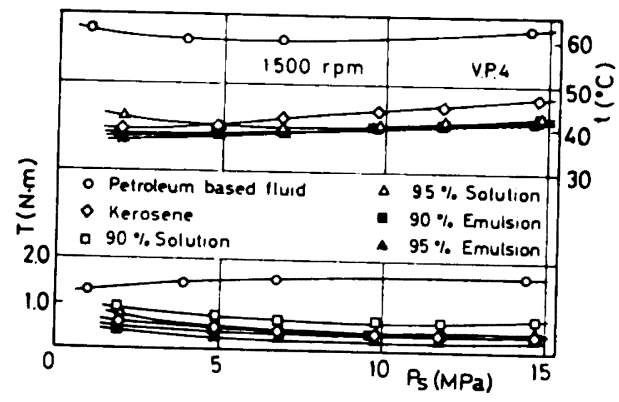

Fig. 14 Valve Plate temperature $t$ and shaft torque T versus Ps for V.P.4

損失動力 $L$ を测定値から

$$
L=p, Q+2 \pi n T
$$

として算出した轺果を，Fig. 15，16に示す。すへての 作勤流体についての結果を求めたV.P. 4 の場合, $p_{s}$ が

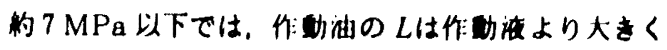
なる．作娌旅の中では，95\%エマルションが小さい.

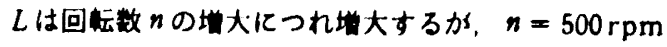
と1500 rpmとの急はわずかである，1500 rpmの㳦合， V.P. 3 と 4 でのLは，灯油，90\%ソリューションか はは闹じ.959\%リューションと90\%エマルションと では，V.P. 3 の方が大きく，p,=10MPaでの侸は90 果ソューションの約 2 倍となっている.

\section{5. 理铪的榙教}

井板とシリンタプロック间のすきま再さについては， 策者の1人か理给解析を行っている゙，その理敦上今 回の実输結果との比较を試みるとととする，たたし，

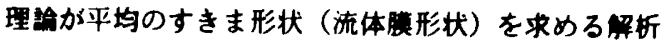
であるため，すきま厚さの変轧しない，すなわち定常 的なくさび滕の形成された埸合を比校の対象とする。

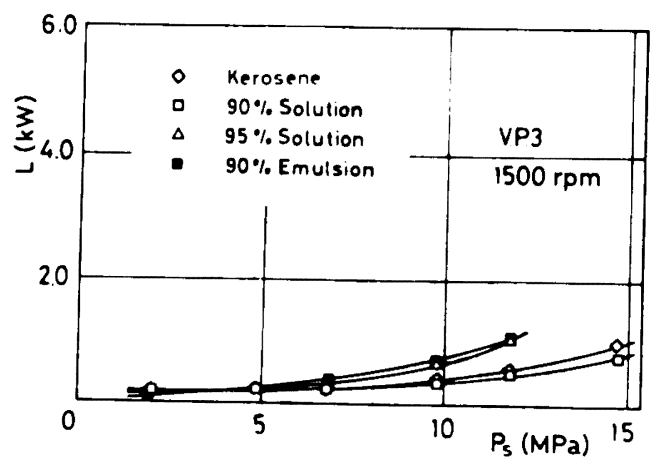

Fig. 15 Lost power L versus Ps for V.P.3

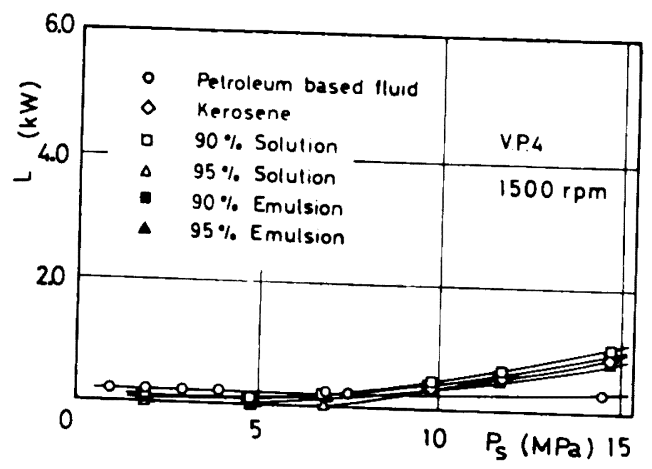

Fig. 16 Lost power L versus Ps for V.P.4 
つまり，Fig.17 に示す流体怔形状

$$
h=h_{0}+\alpha r \cos (\theta-\varphi)
$$

のパラメータ $\left(h_{0}, \alpha, \varphi\right)$ か一定である场合を报う.

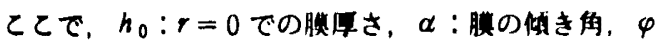

：hの晨大方位角である，また，妯の扱いに対する资 料を得るため，ここではモーメントを支持できる䌷と しての取扱いいを開する。

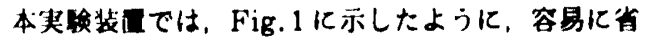
峈できろシリンタフロックなどの自面を除いて㫑们自 はなく，井板ーシリンタプロック間の措助部は2 個所

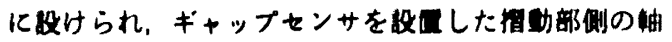
端はニードル岫受で，他端は玉岫受によって支持され ている.

さて、妯の断面 2 次モーメントがで一粎，そのヤ

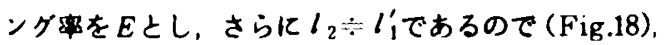
両端固定のはりとして报うと，妯がリンタプロック に及ばすモーメント $(M)$ ，は，例えば

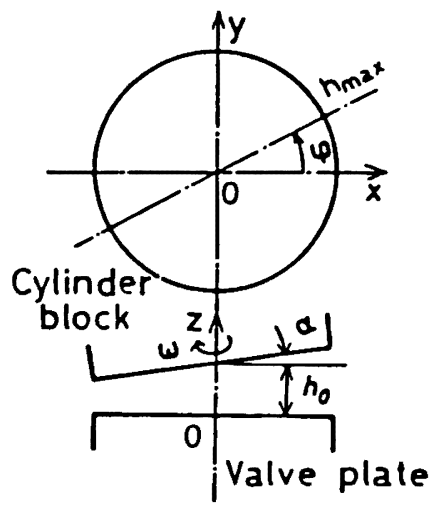

Fig 17 Fluid film shape

$$
\left.\begin{array}{c}
\left(M_{y}\right)_{s}=k \phi_{y} \\
k=-l E I / l_{1}\left(l_{1}-l_{2}\right)
\end{array}\right\}
$$

と表わせる．とこに， $k$ : 軸のば椗数であり，また

$$
\phi,=\alpha \cos \varphi
$$

玉神受側を「支持」すすおち「一端固定他端支持」と して扱うと

$$
k=-\frac{4 l^{3} E I}{3\left(l_{1}^{2}-l_{2}^{2}\right)\left(l^{2}-l_{2}^{2}\right)}
$$

となる。

本実轺装置の場合、シリンタブロックと轴との結合 は，弁板側がスプライン，他端にはめ合い部があるた め、シリンダブロック両端面で軸と接触する，すなわ
ちシリンタフロック長手方向の中央をし、と定める。具 体的に数值を代入すると，两端固定の妯として

$$
\bar{k}=0.102
$$

玉怞受を支持端とした报いでは

$$
\bar{k}=1.25 \times 10^{-3}
$$

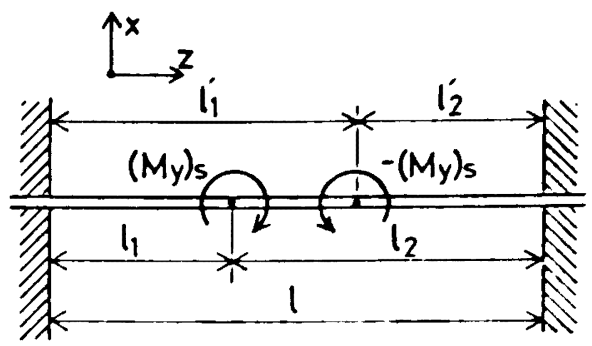

Fig. 18 Moment acting on shaft

となる，なお，後者の扱いでスブライン部中央で搂能 すると仮定すれは， $\bar{k}=3.08 \times 10^{-3}$ となる.念のため. この值とモーメント支持をしないとした报い( $\bar{k}=0.0$ に相当）についても湌討を加える．ただし， $\bar{k}=k /$ $6 \mu \omega R_{c}^{3}\left(R_{c} / H\right)^{3}$ により無次元化している*.

シリンタプックに作用する力（モーメント）のつ り合い式は，定常状意任対し

$$
\left.\begin{array}{l}
\left(\bar{F}_{z}\right)_{1}+\left(\bar{F}_{z}\right)_{1}=0 \\
\left(\bar{M}_{z}\right)_{1}+\left(\bar{M}_{z}\right)_{1}+\left(\bar{M}_{z}\right)_{1}=0 \\
\left(\bar{M}_{y}\right)_{1}+\left(\bar{M}_{3}\right)_{1}+\left(\bar{M}_{y}\right)_{1}=0
\end{array}\right\}
$$

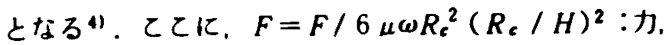
$M=M / 6 \mu \omega R_{c}{ }^{3}\left(R_{c} / H\right)^{2}:$ モーメント，x, y, z: 厚方向を $z$ 轴とした座標，（）,（）、：それぞれ并 板上の流体滕，荷重が及ばす力（モーメント）.

軸のばね作用として、 $\left(M_{s}\right)_{s},\left(M_{y}\right)_{s}$ は，式(4)のよ うに音けるから，式(6)は

$$
\left.\begin{array}{l}
\left(\bar{F}_{z}\right)_{1}+\left(\bar{F}_{z}\right)_{l}=0 \\
\left(\bar{M}_{x}\right)_{1}+\left(\bar{M}_{x}\right)_{l}-\bar{k}_{\bar{\phi}}=0 \\
\left(\bar{M}_{y}\right)_{1}+\left(\bar{M}_{y}\right)_{l}+\bar{k} \bar{\phi}_{y}=0
\end{array}\right\}
$$

となる.ここに

$$
\bar{\phi}_{\mathrm{x}}=\bar{\alpha} \sin \varphi, \quad \bar{\phi}_{\mathrm{y}}=\bar{\alpha} \cos \varphi, \quad \bar{\alpha}=\alpha R_{\mathrm{c}} / H
$$

弁板一シリンダブロック間の圧力分布に基づく值 （・)にについては，リングパッドとした报いを採用す ろ 検装置では，(1)ピストンとシリンダ壁間に作用する度

* $\mu$ : 粘度, $\omega$ : 轴角速度， $R_{c}$ : 弁板ポートピッ千円 半径， $H$ : 代表すきま厚さ 


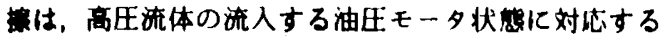
てと，(2)との渭轩部にはのリング (パックアッブリン グ付）が洞れ止めとして装菜されており，また背中合 せのピストン間にるのリングがあること，(3)Oリング

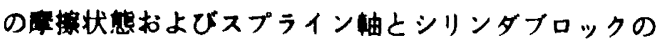

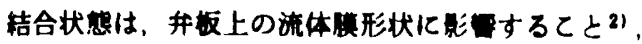
が指揞できる。 このため，バッドの取扱い上の仮定も

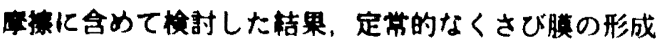
される条件加ら

$$
\begin{aligned}
& \left(\bar{F}_{2}\right)_{1} / \pi \bar{r}_{p}^{2} \bar{p}_{1} \div-3.30 \\
& \left(\bar{M}_{x}\right)_{1} / \pi \bar{r}_{2}^{2} \bar{p}_{1} \div 2.1 \\
& \left(\bar{M}_{y}\right)_{1} / \pi \bar{r}_{,}^{2} \bar{p}_{s} \neq 0.174
\end{aligned}
$$

であるとするのが要当と现められた。ことに、, $\bar{r}_{p}=r_{p}$ $/ R_{\mathrm{c}}$ : ピストン半徍, $\bar{p}_{\mathrm{s}}=p_{\mathrm{s}} / 6 \mu \omega\left(R_{\mathrm{c}} / H\right)^{2}=$

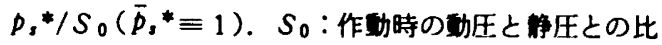
を表わすバラメータ.

摩撩がないとすれ゙，式(8)の右包は，順に一-3.50，

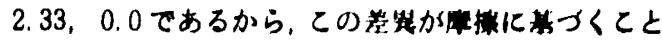

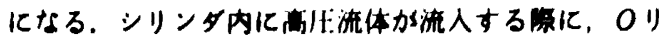

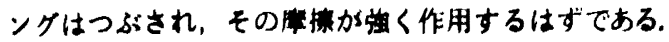
したかって，一つのシリンタ宣に鬲圧流体が流入しは じめてから，次のシリンタ室にそれが流入するまでの

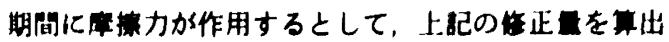
してある.

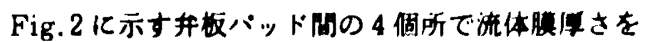

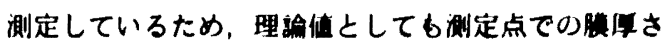
を出した. Table 3 に伷のばか奻果の斯を示す。

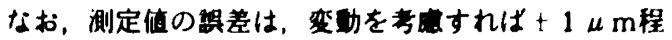
度である。

表から「両端固定」( $\bar{k}=0.102)$ は测定䛧との差か 大きく，扱いが妥当でないてとが分る，「一端固定他 端支持」および「刞のばね勃果無梘」は，ほぼ同じ結 果となった. Table 4は，作䖝油と95\%ソリューショ

Table 3 Effects of shaft elasticity on film thickness: Comparison of theoretical results with experimental results

\begin{tabular}{l||c|c|c|c|c}
\hline \multicolumn{1}{l||}{$\mathrm{h}$} & \multirow{2}{*}{\multicolumn{1}{l|}{ measured }} & \multicolumn{4}{c}{ Calculated, $\overline{\mathrm{k}}$} \\
\cline { 3 - 6 }$\mu \mathrm{m}$ & & 0.0 & $1.25 \times 10^{-3}$ & $3.08 \times 10^{-3}$ & 0.102 \\
\hline $\mathrm{h}_{1}$ & $9.7 \pm 1$ & 9.6 & 9.6 & 9.6 & 11.5 \\
$\mathrm{~h}_{2}$ & 17.8 & 16.7 & 16.7 & 16.7 & 15.7 \\
$\mathrm{~h}_{3}$ & 11.4 & 12.3 & 12.2 & 12.2 & 10.3 \\
$\mathrm{~h}_{4}$ & 7.0 & 5.1 & 5.1 & 5.1 & 6.1 \\
\hline
\end{tabular}

V.P. $2,90 \%$ Solution, $P s=14.7 \mathrm{MPa}, \mathrm{n}=1500 \mathrm{rpm}, \mathrm{h}_{0}=10.9 \mu \mathrm{m}, \mathrm{S}_{0}=1.19$

\begin{tabular}{|c|c|c|c|c|c|c|c|c|c|}
\hline \multirow{2}{*}{\multicolumn{2}{|c|}{$\begin{array}{c}\text { V.P. } \\
\text { Test fluid }\end{array}$}} & \multicolumn{6}{|c|}{2} & \multicolumn{2}{|c|}{3} \\
\hline & & \multicolumn{6}{|c|}{ Petroleum based, ts $=60^{\circ} \mathrm{C}$} & \multicolumn{2}{|c|}{$95 \%$ Solution, $40^{\circ} \mathrm{C}$} \\
\hline Ps & $\mathrm{MPa}$ & \multicolumn{2}{|c|}{15.0} & \multicolumn{2}{|c|}{9.8} & \multicolumn{2}{|c|}{8.8} & \multicolumn{2}{|c|}{9.8} \\
\hline n & $\mathrm{rpm}$ & \multicolumn{2}{|c|}{4000} & & & \multicolumn{2}{|c|}{1500} \\
\hline $\mathrm{h}_{0}$ & $\mu \mathrm{m}$ & \multicolumn{2}{|c|}{15.9} & \multicolumn{2}{|c|}{13.0} & \multirow{2}{*}{\multicolumn{2}{|c|}{$\begin{array}{l}9.5 \\
5.00\end{array}$}} & \multirow{2}{*}{\multicolumn{2}{|c|}{$\begin{array}{l}8.2 \\
1.56\end{array}$}} \\
\hline$S_{0}$ & & & 19 & & .78 & & & & \\
\hline $\mathbf{h}_{1}$ & $\mu \mathrm{m}$ & 13.9 & $(14.9)$ & 11.3 & $(12.4)$ & 8.2 & $(9.7)$ & 8.3 & $(9.4)$ \\
\hline $\mathrm{h}_{2}$ & $\mu \mathrm{m}$ & 18.6 & $(16.6)$ & 15.3 & $(14.0)$ & 11.5 & $(10.0)$ & 14.2 & $(10.2)$ \\
\hline $\mathbf{h}_{3}$ & $\mu \mathrm{m}$ & 17.9 & $(16.9)$ & 14.7 & $(13.5)$ & 10.8 & $(9.2)$ & 8.1 & $(7.4)$ \\
\hline$h_{4}$ & $\mu \mathrm{m}$ & 13.2 & $(-)$ & 10.7 & $(-)$ & 7.5 & $(-)$ & 2.2 & $(5.8)$ \\
\hline
\end{tabular}

Table 4 Comparison of theoretical film thickness with experimental film thickness 
ンの场合の比を示す. $k=1.25 \times 10^{-3}$ としている． 斩圧パッド付の开板では，流体腆の用性が不足する

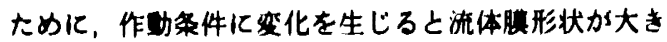
く変化してしまう。との点を怜时するために，V.P.2， 作娌油, $p_{0}=19.7 \mathrm{MPa}, n=1500 \mathrm{rpm}, h_{0}=11.8$ $\mu \mathrm{m}$ から出無して，p，のみが成少するとして，h。の变

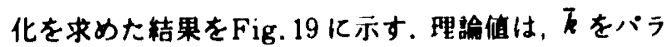

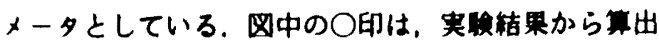
した管価すきまん。であり，腆形状が一㥞でないから， んっはん。より大きくなる.

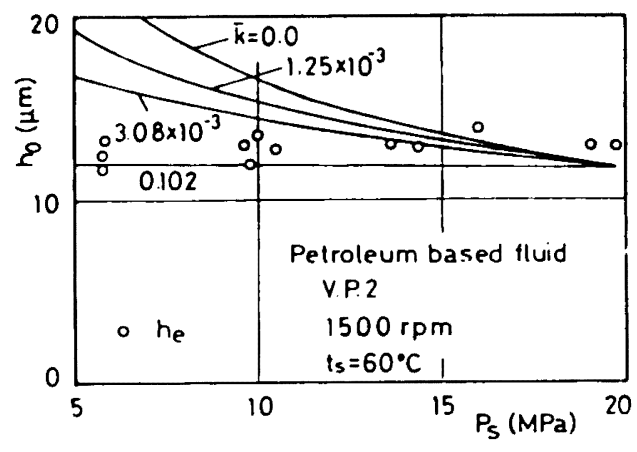

Fig. 19 Fluid film thickness at center $h_{0}$ versus Ps

$\bar{k}=0.102$ の場合，h。ははぼ一定であるが，他はp。 の娍少につれ增大する，すで㫰告した测定値”では， $p_{s}$ の成少につれh。は增大するが，その剖合は $\bar{k}=3.08$ $\times 10^{-3}$ と 0.102 との中間にあると判断される.なお，

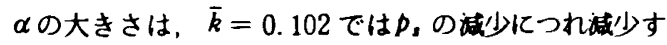
ろが， $\bar{k}=3.08 \times 10^{-3}$ では $8 \mathrm{MPa}$ まではぼ一定，乙 れより低圧で咸少㑯向となる。

本章での比較結果から，乙の盾ポンプ，モー夕の作 動箱囲にわたって，ピストンーシリンタ辟間の摩㨲， 轴のばか効果を通切に予测すれば，理論解析は設計上 の有用な指䧐となると判断できる。

\section{6. むすひ}

ソリューション形とエマルション形要含水作動旅的 らびに低蛅度眝油である奵油を用いて，ピストンポン

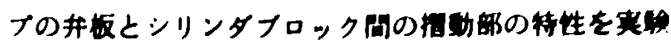

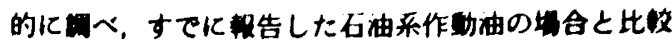
した.

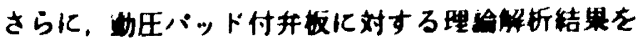

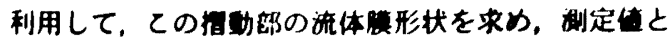
比した。

こてに告した实雅は，日本袖空圧学会，油圧ポン フ・モータの消渭究委员会の活助の一理として实期 されたいのであり，供式并板とシリンタフロックにつ

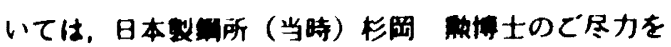
頂いた。こてに此してき意をします。

1）山口・土本：ピストンボンブにおりる并数・シリ ンタフロック間の间清特性，伷压之空気圧，131 (1982), $55 / 60$.

2）山口・水野: 同上(第2 㫰，ソリューション形离 含水作動挔の埸合)，油压之空気压，14-6 (1983)，426/432.

3）山口：ピストンポンフ・モータにおりる并数・シ

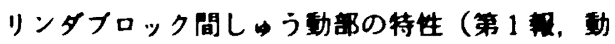
压バット付并板)，日本機械学会铪文集B，51-469 (1985), $2926 / 2930$.

4) Yamaguchi, A. and Shimizu, S.: Design method for fluid lubrication on valve plate of axial piston pumps and motors, Proc 7th Intern Fluid Power Symp., Pap. 3 (1986), 19/28, BHRA. 